\title{
Er reseptspråket verneverdig?
}

La oss bevare latin og gresk i vår medisinske kulturarv.

Kontrasten mellom barokktidens lege som avfatter sin magistrelle resept med fjærpenn og nåtidslegen som benytter e-resept, er stor (fig 1) (1). Siden 2013 brukes elektronisk resept $\mathrm{i}$ alle landets fylker. E-resept har åpenbare fordeler: hurtigere å ekspedere, sikret mot forfalskninger, gir oversikt over alle pasientens resepter, medisinen kan hentes i alle landets apotek, forsinkelser og misforståelser unngås som følge av papirreseptens ofte uleselige håndskrift.

Men når noe vinnes, tapes gjerne noe annet. Utviklingen kan medføre forenkling og fornorsking av reseptspråket, og dermed blir gamle latinske og greske ord og vendinger borte. Jeg mener dette er uheldig når medisinsk historie skal fortelles. Latin har i uminnelige tider vært medisinens grunnspråk og det eneste vitenskapelige meddelelsesmiddel, sammen med en del greske ord, som fremdeles er i bruk. Latin er riktignok for lengst blitt et vikende språk i medisinstudiet, slik det blant annet ble omtalt i Tidsskriftets språkspalte i 2000 (2).

I min studietid i 1950 -årene besto latinundervisningen på doktorskolen av ett semesters pensum og muntlig eksamen med karakterskala 1-4. Dette var sammen med examen philosophicum nødvendig for å avlegge eksamen ved første avdelings første avsnitt. Undervisningen er blitt vesentlig redusert etter hvert. Man trenger åpenbart ikke lenger annet enn norsk språk for å skrive resepter.

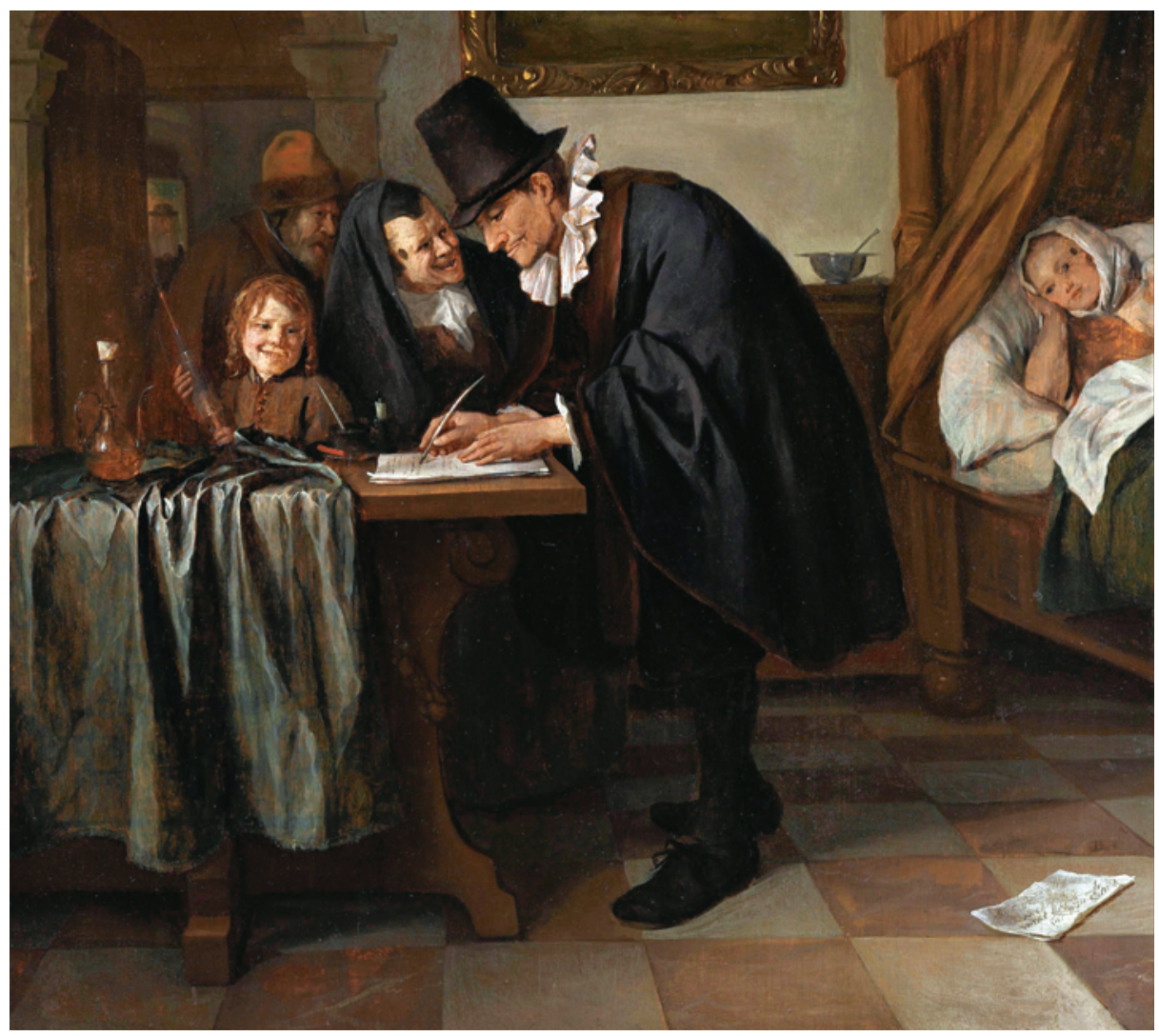

Figur 1 Den nederlandske barokkmaleren Jan Steen (1626-79) har malt tallrike legebesøk. Her er lege og pasient i forgrunnen, i tillegg til andre skuelystne. Legen, som skriver resept, forstyrres av en kvinne - er det hushjelpen? Det synes å herske en munter stemning. Museum Boijmans Van Beuningen, Rotterdam, Nederland. Wikimedia Commons

Tabell 1 Eksempler på fortsatt gangbare reseptspråkforkortelse

\begin{tabular}{|c|c|c|}
\hline Forkortelse & Latin & Norsk \\
\hline Rp. & Recipe & $\mathrm{Ta}$ \\
\hline$\#$ & Invocatio & $\begin{array}{l}\text { Dobbeltkorset, påkallelse (Deo juvante eller Dei gratia, med Guds hjelp } \\
\text { eller av Guds nåde). Dobbeltkorset er vel på vei ut. Det figurerer nå } \\
\text { overalt i kursiv, og påtreffes som «firkanttasten» på datamaskiner og } \\
\text { mobiltelefoner, «hashtag», og symbolet for transportselskapet «Ruter» }\end{array}$ \\
\hline D.s.s.n. & $\begin{array}{l}\text { Detur signetur } \\
\text { sui nomine }\end{array}$ & Gi, undertegn med medikamentets navn og bruksanvisning \\
\hline Reit. & Reiteretur I,II,III, semel, bis, ter & Gjenta resepten én, to eller tre ganger \\
\hline Ad us. propr. & Ad usum proprium & Til eget bruk \\
\hline Tabl. & Tablettae & Tabletter \\
\hline Pil. & Pilulae & Piller \\
\hline Ungv. & Unguentum & Salve \\
\hline Gtt. & Guttae & Dråper \\
\hline
\end{tabular}


For noen år siden skrev jeg min siste resept til meg selv. I apoteket ble jeg spurt om ad usum proprium var pasientens navn!

Jeg har henvendt meg til våre fire medisinske fakulteter og Farmasøytisk institutt ved Universitetet i Oslo for å undersøke i hvilket omfang reseptlære blir undervist. Jeg fikk inn tre svar. På medisinstudiet ved Universitetet i Bergen foreleses, inklusiv enkelte praktiske øvelser, tre timer i femte studieår (Ø. Hetlevik, personlig meddelelse). Ved medisinstudiet i Trondheim gis én forelesning i femte studieår (H.M. Tunaal, personlig meddelelse). Ved farmasistudiet i Oslo gis to forelesninger i andre studieår (Å. Ertesvåg, personlig meddelelse).

Det sies gjerne at legenes latinkunnskaper er blitt så dårlige at man må ty til forkortelser for ikke å avsløre manglene. Men leger og farmasøyter korresponderer stort sett uten problemer ved resepter som fortsatt kan skrives på «latin» (tab 1). Det synes ikke å være velbegrunnet med forenkling eller fornorsking av deres språk. Jeg mener det vil være et stort tap for vårt fag dersom vi nå er i ferd med å miste denne siste rest av vår klassiske kulturarv.

Farmasi inngår med stor tyngde i medisinsk historie på grunn av alle fellesnevnere mellom de to fagene. Reseptspråket er en slik viktig fellesnevner, og europeisk farmasi tilhører vår medisinske historie.

La oss for en kommende og ønskelig diskusjon minnes Ludvig Holbergs Jeppe paa Bierget (utgitt 1723) der det i dialog mellom to tilkalte «Doctores» uttales: «Quid tibi videtur, domine frater?» Hva synes du, broder i faget (3).

\section{Jacob Klafstad}

jklaf@broadpark.no

Jacob M. Klafstad (f. 1934) er pensjonert lege og tannlege og spesialist i maxillofacial kirurgi.

\section{Litteratur}

1. Petterson E. Amans amanti medicus: Das Genremotiv Der ärztliche Besuch in seinem kulturhistorischen Kontext. Doktoravhandling. Oslo: Universitetet i Oslo, 1990.

2. Holck P. Latin i Norge og Norden. Tidsskr Nor Lægeforen 2000; 120: 2194.

3. Evensberget S, Gundersen D. Bevingede ord. 4. utg. Oslo: Kunnskapsforlaget, 2006: 412. 